Ristekdik (Jurnal Bimbingan dan Konseling)

Vol.6,No.2, 2021, hlm.239-244

DOI: http://dx.doi.org/10.31604/ristekdik.2021.v6i2.239-244

\title{
Peran Orang Tua Dalam Membimbing Karir Anak
}

\author{
Murti Muninggar \\ Universitas Islam Negeri Sunan Kalijaga Yogyakarta \\ murtimuninggar0912@gmail.com
}

\begin{abstract}
The role of parents in guiding a child's career is very much needed, because without the support and motivation of the parents, the child will not succeed in achieving a carrer. The role of parents is also very influential in a child's life, on of which is the child's needs. This study aimas to determine: What is the wole of parents in guiding childre's careers. This study focuses on examining the role of parents in guiding children's careers. This study uses the literature method or literature review with the nature of descriptive analysis research. Based on the results og this study, it is found that the role of parents in guiding their children's career includes: parents as facilitators, parents as motivators and parents as role models. In addition, parents also provide guidance on children's careers which will produce positive things towards their carreers
\end{abstract}

Keywords: Parents, Career, Children

\begin{abstract}
Abstrak: Peran orang tua dalam membimbing karir anak sangat dibutuhkan, karena tanpa adanya dukungan dan motivasi dari orang tua, anak tersebut tidak akan berhasil dalam mencapai suatu karir-nya. Peran orang tua juga sangat berpengaruh didalam kehidupan seorang anak yang salah satunya yaitu kebutuhan anak. Penelitian ini bertujuan untuk mengetahui: Bagaimana peran orang tua dalam membimbing karir anak. Penelitian ini berfokus untuk mengkaji peran orang tua dalam membimbing karir anak. Penelitian ini menggunakan metode kepustakaan atau kajian literarur (literature review) dengan sifat penelitian analisis deskriptif. Berdasarkan hasil penelitian ini menemukan adanya peran orang tua dalam membimbing karir anaknya diantaranya: orang tua sebagai fasilitator, orang tua sebagai motivator dan orang tua sebagai panutan, Selain itu orang tua juga memberikan bimbingan terhadap karir anak yang akan menghasilkan hal positif terhadap karirnya
\end{abstract}

Kata kunci: Orang tua, Karir, Anak

\section{PENDAHULUAN}

Dengan kemajuan ilmu Pengetahuan dan Teknologi (IPTEK), yang semakin hari semakin berkembang pada kehidupan saat ini akan mempermudah untuk mencari informasi yang diinginkan. Dengan adanya teknologi semua informasi dapat diakses dengan cepat dan mudah dengan segala bentuk yang baik yang berdampak negatif maupun dampak positif yang ditimbulkan baik untuk individu maupun bagi orang lain apalagi dengan perkembangan dunia pendidikan jarak, ruang, dan waktu bukan lagi penghalang bagi manusia untuk mencari tau. Oleh karena itu, orang tua harus ikut berperan aktif untuk melihat kondisi yang semakin hari maju ini. Akan tetapi dengan adanya teknologi yang canggih ini juga seseorang juga bisa memperoleh suatu informasi pekerjaan yang ia minati dan sesuai dengan profesinya yang disenanginya serta dengan kesesuaian ini maka individu tersebut bisa menyukai dari sebuah pekerjaan yang individu lakukan. 
Pada dasarnya manusia merupakan makhluk sosial yang diciptakan oleh Allah untuk selalu meminta pertolongan kepada orang lain, begitu juga dalam sebuah kehidupan keluarga yang salah satunya yaitu peran orang tua terhadap karir anak. Tanpa adanya peran orang tua maka anak tersebut akan mendapatkan kesulitan dalam mencapai citacitanya. Peran orang tua merupakan dasar yang paling penting dalam membimbing karir anak yaitu dengan mendidiknya anak yang baik (Gading et al., 2020). Dalam membimbing karir peran orang tua sangatlah dibutuhkan, karena untuk memberikan bekal kepada anaknya, selain itu orang tua tidak mau anaknya lebih bodoh lagi seperti mereka, karena menurut mereka anak merupakan salah satu generasi penerus yang harus dijaga. Anak bagi orang tua merupakan harta yang terindah bagi mereka, walapun sejelek apapun anak nya maka akan tetap menjadi anaknya. Orang tua berjuang banting tulang agar kehidupan anaknya menjadi layak, memiliki pekerjaan yang bisa menopang kehidupan anaknya nanti, bukan menjadi seorang pengangguran yang meresahkan masyarakat dan bukan juga menjadi preman kampung yang tidak memiliki skill apapun akan tetapi menjadi figure bagi masyarakat yang bisa membimbing masyarakat kejalan yang benar. Maka dari itu orang tua bertekat untuk bisa mendidik anaknya sesuai dengan kemampuan dari orang tuanya.

Manusia diciptakan oleh Allah dari berbagai macam kehidupan dan berbagai macam kesuksesan dalam karir seorang anak.
Tanpa dukungan dari orang tua karir seorang anak anak akan jarang sekali bisa berhasil walaupun ada beberapa orang yang berhasil akan tetapi sangat sedikit sekali, jika orang tua memiliki harta yang cukup terkadang anaknya yang malas untuk menunjang karir-nya begitupun pula sebaliknya inilah yang terjadi pada saat ini. Karir adalah profesi seseorang yang bekerja dengan senang hati dan penuh kegemberian apabila apa yang dikerjakan itu memang sesuai dengan keadaan individu yang sesuai dengan kemampuan dan minat (Rahmat, 2020), sebaliknya jika seseorang bekerja tidak sesuai dengan dirinya dan minatnya maka dapat dipastikan bahwa ia akan kurang bergairah dalam suatu pekerjaan itu, kurang senang dan kurang tekun, Agar seseorang dapat bekerja dengan baik tenang dan tekun diperlukan adanya kesusaian tuntunan dari pekerjaan atau jabatan itu dengan apa yang ada didalam diri individu yang bersangkutan untuk mengarah ke hal tersebut, diperlukan bimbingan secara baik dan hal tersebut merupakan salah satu tugas dari seorang pembimbing untuk mencapai pemahaman dan pengarahan diri secara maksimal kepada keluarga dan masyarakat.

Di dalam layanan bimbingan konseling ada salah satu layanan bimbingan yang diberikan orang tua kepada anaknya yaitu bimbingan karir. Menurut Sitti Rahmaniar Abubakar (2011) mengatakan bahwa bimbingan karir merupakan layanan yang diberikan konselor kepada klien dengan tujuan agar individu bisa memahami dirinya sendiri dan bisa mengambil keputusan yang ia ambil 
dalam menunjang karir individu baik dari karir pendidikan maupun dari karir pekerjaan guna untuk mencapai kesuksesaan dari individu itu sendiri.Sedangkan menurut Atmaja, (2014) bimbingan karir adalah suatu usaha untuk mengetahui dan memahami dirinya sendiri dengan suatu pekerjaan yang ia ambil agar individu tersebut bisa mandiri dan bisa mengambil keputusan yang terbaik untuk dirinya.

Dengan diberikan bimbingan karir yang dilakukan orang tua kepada anaknya dengan tujuan yaitu agar individu tersebut bisa mengambil keputusan yang terbaik yang diberikan orang tuanya mengenai karir-nya, tanpa adanya dukungan dan bimbingan dari orang tua maka anak tersebut tidak akan berhasil untuk mencapai sebuah karir yang sukses. Disamping itu orang tua memiliki tanggung jawab dan peran penting dalam suatu kebutuhan anak, ada berbagai macam kebutuhan anak diantaranya kebutuhan material dan non material yang sesuai dengan kebutuhan anak tersebut.

Pada dasarnya layanan informasi karir ini terdiri dari fakta-fakta mengenai pekerjaan, jabatan atau karir yang bertujuan untuk membantu individu memperoleh pandangan, dan pemahaman tentang dunia kerja serta aspek-aspek dunia kerja (Tohirin, 2007). Ratarata anak yang suskses adalah orang-orang yang mengikuti bimbingan dari orang tua-nya,orang tua mendukung dan memotivasi anaknya walaupun dengan berbagai macam cara baik itu dengan cara berhutang atau dengan menjual harta kekayaan. Inilah kenapa peneliti merasa tertarik untuk meneliti lebih lanjut tentang bagaimana peran orang tua dalam membimbing karir anak.

\section{METODE}

Pada penelitian ini penulis menggunakan metode kepustakaan atau kajian literatur (literature review).Dalam kajian pustaka ini bisanya disebut dengan kajian literatur yang dimana mengkaji dan menguraikan mengenai literatur tertentu yang membahas sebuah topik, dimana kajian ini sebelumnya telah membahas atau telah dibicarakan oleh peneliti, Sumber data yang didapatkan dari sebuah buku dan artikel yang sesuai dengan permasalahan peneliti mengenai bagaimana peran orang tua dalam membimbing karir anak.

Batubara, (2015) mengatakan bahwa Literature merupakan suatu rujukan, acuan atau sumber yang digunakan dalam sistem pendidikan untuk mendapatkan sebuah informasi tertentu yang dibutuhkan oleh peneliti, literature ini bisa berupa buku atau artikel. Literature review ini juga bisa dikatakan dengan suatu kajian yang sangat kritis yang mengkaji sebuah penelitian terdahulu serta sebuah alat yang sangat penting bagi sebuah contect review, literature ini sangat berguna untuk membantu dalam sebuat konteks penulisan yang sedang dilakukan oleh peneliti dan dengan melalui literature ini peneliti juga dapat secara eksplisit serta seorang pembaca mudah mengetahui maksud dari sebuah penelitian tersebut (Affifudin, 2014). Sifat dari 
penelitian ini yaitu analisis deskriptif, dimana penguraian secara teratur data yang telah diperoleh,lalu diberikan pemahaman serta penjelasan agar mudah dipahami dengan baik oleh pembaca (Cholid Narkobu, 2015)

\section{HASIL DAN PEMBAHASAN}

Didalam kehidupan keluarga peran orang tua sangatlah penting dalam membimbing dan menunjang karir anak, karena orang tua merupakan salah satu kunci dari keberhasilan seorang anak, tanpa adanya dukungan dan motivasi dari orang tua maka tidak menutup kemungkinan anak tersebut akan tidak akan berhasil dalam mencapai karir-nya. Peran dapat diartikan sebagai suatu perilaku yang dilakukan oleh seseorang untuk menempatkan suatu hak dan kewajiban yang sesuai dengan kedudukan yang ia tempatkan. (Soekanto, 2002).

Peran orang tua disini memiliki kedudukan dan hak untuk membimbing karir anak yang bertujuan untuk mencapai suatu kesuksesaan untuk masa depan anaknya. Peran orang tua juga memiliki tanggung jawab terhadap memfasilitasi kebutuhan anak dalam suatu pendidikannya hingga karir seorang anak, peran orang tua sangat berpengaruh didalam kehidupan seorang anak. Orang tua juga diharapkan mampu untuk mengayomi terutama disaat anak menghadapi kesulitan sehingga anak merasa aman, dan senang hidup bersama keluarga Sedangkan bimbingan karir disini menjelaskan bahwa suatu layanan yang diberikan konselor kepada konseli dengan melalui pertumbuhan, perkembangan serta mengambil keputusan karir yang indiidu ambil dalam suatu lingkungan hidupnya yang bertujuan untuk mencapai kesuksesaan bagi diri individu sendiri. (Fara (2017) Dalam memberikan bimbingan terhadap karir anak para orang tua selalu berusaha keras dalam mencukupi kebutuhan anak-anaknya dengan tujuan untuk melihat anaknya karir anak kemasa depan yang baik.

Tujuan bimbingan karir yaitu supaya anak memahami potensi yang dimiliki dengan baik dan mengetahui pekerjaan dan persyaratan-persyaratan apa saja yang harus dipenuhi agar terbentuk suatu kecocokan dengan potensi yang dimilikinya. (Soekanto, 2002). Bentuk bimbingan yang diberikan orang tua kepada anaknya yang pertama yaitu mencukupi kebutuhan anak, setiap anak memiliki kebutuhan dasar dan setiap anak memiliki kebutuhan-kebutuhan secara khusus karena itu orang tua seharusnya mengerti apa yang menjadi kebutuhan dasar seorang anak dan setiap anak memiliki proses perkembangan. Yang kedua kerja keras, kerja keras menjadi salah satu sikap yang dimiliki oleh masingmasing orang, orang tua sering mencontohkan sikap kepada anaknya dengan tujuan agar anaknya menirukan yang dicontohkan oleh orang tuanya. Etos kerja tidak selalu berupa kerja keras saja, tetapi lebih dari itu orang yang memiliki etos kerja yang baik akan memiliki sikap yang terpuji. Dan orang yang memiliki etos kerja memiliki sikap tanggung jawab, disiplin, dan berpikir positif . 
Orang tua memiliki tanggung jawab dan peran dalam membentuk serta membimbing anak-anaknya baik dari segi psikologis maupun pisiologis (Pujiastuti \& Barat, 2018).Orang tua dituntut dapat mengarahkan, mendidik dan membimbing anaknya agar menjadi anak-anak mandiri serta menjadi anak yang sukses. Sahaludin (2010) mengatakan bahwa ada peran orang tua dalam membimbing karir anak adalah kewajiban untuk memberikan bimbingan dan arahan kepada anak. Peran orang tua dalam membimbing anak diantaranya: (1) sebagai fasilitaor, peran orang tua dalam membimbing karir anak untuk masa depannya selalu dipenuhi oleh orang tua-nya terutama dalam hal pendidikannya, oleh sebab itu orang tua sangat memperhatikan kebutuhan-kebutuhan anaknya untuk menjadi orang yang sukses. (2) Sebagai motivator selain sebagai fasilitator orang tua berperan sebagai motivator dalam menghadapi masa peralihan menuju dewasa. Anak selalu membutuhkan dorongan dan semangat dari orang tua terutama pada saat mengalami kegagalan dengan adanya dorongan dan semangat dari orang tua anak akan lebih percaya diri dan penuh semangat pantang menyerah terhadap segala bentuk halangan yang dialami. (3) Sebagai panutan, orang tua menjadi suri teladan atau memberi contoh yang baik kepada anaknya baik dari hal sikap dan perilaku sehari-hari, dengan demikian anak dapat bersikap dan berprilaku sesuai dengan norma agama dan norma-norma yang berlaku dimasyarakat. Orang tua mengajarkan etika, mengajarkan sopan santun terhadap sesame dan mengajarkan kejujuran. Orang tua wajib menjadi panutan bagi seorang anak untuk menuju kesuksesan.

\section{KESIMPULAN}

Dari hasil pemaparan diatas penulis menyimpulkan bahwa peran orang tua dalam membimbing karir anak sangat dibutuhkan, karena tanpa adanya dukungan dan motivasi dari orang tua anak tersebut tidak akan berhasil untuk mencapai sebuah karir. Peran orang tua juga sangat berpengaruh didalam kehidupan seorang anak yang salah satu yaitu kebutuhan anak. Peran orang tua dalam membimbing karir anak diantaranya yaitu orang tua sebagai fasilitaor,orang tua sebagai motivaotor dan orang tua panutan yang baik bagi anak

\section{DAFTAR RUJUKAN}

Affifudin. (2014). Metodologi Penelitian Kualitatif, Bandung (Pustaka Setia).

Atmaja, T. T. (2014). Upaya Meningkatkan Perencanaan Karir Siswa Melalui Bimbingan Karir dengan Penggunaan Media Modul. 3(2).

Batubara, A. K. (2015). Literatur Informasi Dan Kepustakaan, Vol.09, 134.

Cholid Narkobu, A. A. (2015). Metodologi Penelitian, Jakarta (Bumi Aksari).

Fara, E. L. (2017). Bimbinga Yang Klasik Aktif Dan Menyenangkan, Bimbingan Dan Konseling, Bandung (CV Rasi Terbit).

Gading, K., Kota, C., \& Amaliyah, A. (2020). Peran Orang Tua Karir dalam Mengembangkan Karakter Religiusitas Anak ( Studi di Komplek Pepabri Blok B . 3 No . 21 RT . 15 Kelurahan Lingkar Barat Info Artikel Keyword Kata Kunci Abstrak. 2(1), 54-63.

Sitti Rahmaniar Abubakar. Pelaksanaan Bimbingan Karir Bagi Siswa Sma Sebagai Persiapan Awal Memasuki Dunia Kerja (2011). 1(1410-2323), 138. 
Pujiastuti, F., \& Barat, J. (2018). Penerapan

Layanan Informasi Karir untuk

Meningkatkan Pemahaman Siswa dalam

Pengambilan Keputusan Karir. Jurnal Penelitian Pendidikan, 18(2), 160-170.

Rahmat, Z. (2020). Pusat Bimbingan Karir (Career Centre) Sebagai Sarana Bimbingan Karir Bagi Mahasiswa Pendidikan Ekonomi Menuju Dunia Kerja. Al-Ittizaan: Jurnal Bimbingan Konseling Islam, 2(2), 27. https://doi.org/10.24014/0.878945

Sahaludin, A. (2010). Bimbingan Dan Konseling, Bandung (Pustaka Setia).

Soekanto, S. (2002). Sosiologi Suatu Pengantar, Jakarta (Rajawali Press).

Tohirin. (2007). Bimbingan Dan Konseling Sekolah Dan Madrasah, Jakarta(PT.Raja Grafindo Persada). 